\title{
CYP2D6*1 Allele
}

National Cancer Institute

\section{Source}

National Cancer Institute. CYP2D6*1 Allele. NCI Thesaurus. Code C45616.

Human CYP2D6*1 allele is located in the vicinity of $22 \mathrm{q} 13.1$ and is approximately $4 \mathrm{~kb}$ in length. This allele, a variant form of the CYP2D6 wild-type allele, encodes cytochrome P450 2D6*1 protein. There are multiple haplotypes of the CYP2D6*1 allele. The nucleotide sequence of CYP2D6*1A is identical to that of the wild-type allele and exhibits no mutations. Four other haplotypes of the CYP2D6*1 allele exhibit SNPs that have no effect on the enzymatic activity of the corresponding cytochrome P450 2D6*10 proteins. 